\title{
Phylogeny and biogeography of the Niphargus transitivus group of species (Crustacea, Amphipoda)
}

\author{
Boris Sket ${ }^{1} \&$ Jos Notenboom ${ }^{2}$ \\ ${ }^{1}$ Department of Biology, Biotechnical Faculty, University of Ljubljana, Aškerčeva 12, 61000 Ljubljana, \\ Slovenia; ${ }^{2}$ National Institute of Public Health and Environmental Protection, P.O. Box 1, \\ 3720 BA Bilthoven, The Netherlands
}

Keywords: Amphipoda, Niphargus, phylogeny, zoogeography

\begin{abstract}
The Niphargus transitivus group includes 12 groundwaterdwelling species. It is defined by an upright body position during locomotion, a small, stout body with short appendages, except for long coxae and dactyli, coxae V-VI equilobate or posterolobate, accessory flagellum subject to reduction, and the body endowed with adaptations for volvation ( $=$ ability to enroll into a ball).

The biogeography of this southeastern European group of species is discussed and a cladistic analysis of the group is presented. Some cases of parallel character evolution in groundwater amphipods are mentioned. The inference of biogeographic and phylogenetic information in elucidating the evolutionary history of the group is hampered by inconsistency of the data. One of the hypotheses about the evolutionary history of the group is thought to be the most parsimonious.
\end{abstract}

\section{Résumé}

Le groupe transitivus du genre Niphargus comprend 12 espèces souterrains. Il est défini surtout par la position verticale du corps pendant le déplacement, par un corps petit et trapu aux appendices courts (à l'exception des longues coxae et dactyli), par les coxae V-VI equilobés ou posterolobés, par le flagelle accessoire sujet à une réduction accusée, et par le corps doué d'adaptions permettant la volvation.

La biogéographie de ce groupe d'espèces d'Europe du S.E. est discutée et une analyse cladistique est présentée. Sont mentionnés certains cas d'évolution parallèle des caractères chez des Amphipodes souterraines. L'utilisation de l'information biogéographique et phylogénétique dans le but de l'élucidation de l'histoire évolutive du groupe est rendue difficile par le caractère contradictoire des données. Une des hypothèses sur l'histoire évolutive du groupe est considérée comme étant la plus parcimonieuse.

\section{Introduction}

The Niphargus transitivus group was introduced by Sket (1971) to delimitate four species of Niphargus Schiödte, 1849, which on the one hand were all very aberrant, but on the other hand intermediate in some characters between $N$. kochianus Bate, 1859 , and Karamaniella Sket, 1962. The latter genus was erected for $K$. pupetta Sket, 1962, a species which did not fit within the Niphargus diversity spectrum at the time. At present Karamaniella is considered synonymous with Niphargus, and $K$. pupetta has been incorporated into the $N$. transitivus group (cf. Sket, 1972: 106, 111; Karaman, 1975). For the related but morphologically very distinct $K$. paradoxa (Sket, 1964) the genus Carinurella Sket, 1971, has been established.

Since establishment of the $N$. transitivus group, several additional taxa have been described by Dancău (1971), Karaman (1972, 1984a, 1989), and Karaman \& Sket (1991). Moreover, after reanalysis of the previously known but insufficiently described N. kochianus longidactylus Ruffo, 1937, it appeared to belong to the $N$. transitivus group as well (cf. Sket, 1971; Karaman, 1981).

Altogether 12 nominal species are now considered as the $N$. transitivus group, and we decided to treat the systematics, phylogeny, and biogeography of this group of Niphargus species more properly as a whole. 
2. Definition and peculiarities of the Niphargus transitivus group

\subsection{List of species and distribution}

The following taxa compose the $N$. transitivus group:

- N. carcerarius G. Karaman, 1989; only two specimens (!) found in a small cave lake near Pljevlja (cave of Šljivanski potok near Djurdjevića Tara), northern Montenegro (Karaman, 1989).

- $N$. asper G. Karaman, 1972; only one specimen (!) found in a well near Podgorica (= Titograd), Montenegro (Karaman, 1972).

- N. factor G. Karaman \& Sket, 1991; inhabitant of small cave lakes in lower parts of Popovo polje (Vjetrenica at Zavala; Baba pećina at Strujići), southeast Hercegovina (Karaman \& Sket, 1991). This species is very similar to $N$. asper; both may be varieties of a single species.

- N. brevirostris Sket, 1971; only two specimens (!) found in interstitial waters of the Gacko polje (at Ličko Lešće) in Lika, southwest Croatia (Sket, 1971).

- N. numerus G. Karaman \& Sket, 1991; only one specimen (!) found in a small residual lake of an active cave near Zrmanja River (Ćavlinska pećina), near Obrovac, northern Dalmacija (Karaman \& Sket, 1991). N. brevirostris and $N$. numerus also show many similarities pointing to their possible conspecifity.

- N. pectinicauda Sket, 1971; inhabitant of interstitial waters of the Sava River between Bohinj and Ljubljana, northwest Slovenia (Sket, 1971; Sket \& Velkovrh, 1981).

- $N$. rostratus Sket, 1971; found in small lakes of a cave near Cetina River (Dragića pećina at Maljkovo), central Dalmacija, Croatia (Sket, 1971).

- N. alutensis Dancău, 1971; probably an inhabitant of interstitial waters of the Olt River valley (found in wells, village Jilbea), south-central Rumania (Dancău, 1971).

- N. longidactylus Ruffo, 1937; inhabitant of interstitial waters, able to build large populations in open wells near rivers outside karst areas, in northeast Italy, and in central and northeast Slovenia, northwest Croatia, central and north- west Bosnia (Ruffo, 1937; D’Ancona, 1942a \& b; Benedetti, 1942; Karaman, 1981; Sket \& Velkovrh, 1981).

- N. transitivus transitivus Sket, 1971; found directly in interstitial waters and in wells along Piave and Torre in northeast Italy, occasionally also in caves at the karst margins in the same area (Sket, 1971; Karaman, 1975, 1984a, 1985).

- N. transitivus dissonus G. Karaman, 1984; found in wells in the Bergamo region, northern Italy (Karaman, 1984a, 1985). Sket (1971) opened the question of a possible conspecifity of $N$. transitivus with $N$. pupetta, according to the great variability of some $N$. transitivus populations. Karaman (1975) denied this possibility since he found no intermediate specimens in mixed populations, but we think that more material should be examined before the last decision is conclusive.

- N. pupetta pupetta (Sket, 1962) (syn.: Karamaniella pupetta Sket, 1962); found in interstitial waters and wells in Bergamo and probably in Belluno regions in north and northeast Italy, as well as in northwest (Bovec, new data), central, and eastern Slovenia (Sket, 1962, 1972; Karaman, 1975, 1984a).

- N. pupetta parapupetta G. Karaman, 1984 (syn.: $N$. parapupetta in Karaman, 1984a, and Karamaniella pupetta in Dancău, 1972); found in interstitial waters and wells near Zagreb, western Croatia, and near the river Dunarea-Dunav (Danube) in southwest Rumania. This taxon was described as a separate species. Since it seems to be completely allopatric to N.p. pupetta, and the differences are extremely small, we now suggest that both taxa are conspecific.

- Carinurella paradoxa (Sket, 1964) (syn.: Karamaniella paradoxa Sket, 1964); found in interstitial waters of the lower reaches of Soca-Isonzo and its tributaries: Vipava, Torre-Ter, and Nadiža-Natisone, all on both sides of the Sloveno-Italian boundary (Sket, 1964, 1971, 1972). Although attributed to a separate genus, this species has drawn much concern. The acceptability of making the genus (Niphargus) paraphyletic has been discussed elsewhere (Sket, 1990).

In conclusion, the representatives of the $N$. transiti- 
vus group are not all sufficiently characterized, primarily because of lack of material. Information about morphological variation within and between adjacent populations is lacking and the possibility that some of the nominal species are merely intraspecific varieties must be considered.

The group includes taxa that are evidently members of the benthos in larger water bodies of the karst; a quite remarkable feature, since in the Dinaric karst such an ecology is mostly exhibited by larger niphargids of a centimetre or larger. Other members of the group inhabit interstitial waters in river valleys, some also in hilly country (N. Iongidactylus), but all species may build denser populations in open wells - either in response to greater space or to richer food supplies that are usually present there. Therefore, the group as a whole, as well as some of the species, appears as quite ubiquitous stygobiontic animals. Some species $(N$. brevirostris, $N$. numerus, and $N$. asper) were found in so few numbers that their ecology remains uncertain.

The known distribution area of the group reaches from Bergamo in northern Italy to the Olt River in Rumania; below the southern slopes of the Alps and along the southern parts of the Danube system, as well as in the Dinaric karst. While cave species of the Dinaric karst seem very limited in distribution, ranges of interstitial species may be extraordinarily extended. Comparable zoogeographical connections between northeastern Italy and southern parts of the Danube system have already been noted in other groups (e.g., Sket, 1972, and in prep.). They obviously originated under influence of corresponding paleogeographical events.

There exists a number of taxa in the $N$. kochianus group, showing some similarities with members of the $N$. transitivus group (e.g., slender dactyli, see $N$. wolfi Schellenberg, 1933, and N. "kochianus" melticensis Dancău \& Andreev, 1973). Supposedly the similarities of these taxa are homoplasies, since a high probability exists for convergent character evolution in niphargids (mosaic evolution). Of course, prior to a detailed analysis of the whole genus it is impossible to know whether the $N$. transitivus group is delimited correctly (i.e., if the group is monophyletic).

\subsection{Characterization of the $\mathrm{N}$. transitivus group}

2.2.1. Analysis of characters. - The most constant characters of the Niphargus transitivus group (some apparently synapomorphies) are: body size small to very small, stout and upright-walking; coxae of pereiopods II-III very deep, at least twice as deep as wide; coxa of pereiopod $\mathrm{V}$ equilobate or posterolobate, that of VI posterolobate; bases of posterior pereiopods broad, with widely rounded distoposterior lobes; dactyli of pereiopods very slender and long; gnathopods basically of the $N$. kochianus type (synapomorphy of a wider group?). However, there exists a number of characters, present in some of the taxa, that are functionally connected by the above-mentioned characters and absent in other niphargids.

We will try to evaluate all specific character states appearing in the $N$. transitivus group. Character state polarity is determined mainly by comparison with species of the $N$. kochianus complex which apparently is the most closely related to the $N$. transitivus group and considered as a sister group.

Habitus: The body is small to extremely small, short and broad, not depressed; the stout appearance is emphasized by deep coxae and short distal parts of appendages. $N$. carcerarius, with a length of $11 \mathrm{~mm}$ or more, is by far the largest member, but its taxonomic position within the group is uncertain. All other taxa are only 2-6 mm long, being among the smallest of the niphargids. The urosome has been greatly modified in Carinurella paradoxa.

Rostrum: Some species of this group are exceptions among niphargids, having a conspicuous rostrum. In most taxa it is only slightly indicated. In $N$. brevirostris it is well developed, and it is exceedingly long (equal to lateral cephalic lobes) in $N$. rostratus. As this feature was neglected until the discovery of this group, it is impossible to establish its condition in other niphargids.

Epimera: The ventroposterior angles of the epimera in niphargids are rounded or obtuse, to acute. Either of these shapes seem to have developed convergently, but it is often quite constant for larger groups of taxa. In the group studied, only $N$. carcerarius exhibits rectangular angles, whereas epimeral plates in all other species end in acute 
angles. With the above-mentioned exception, in all species of the $N$. transitivus group the ventral (i.e. apical) parts of epimera II-III (sometimes I-III) are strongly produced in ventrocaudal direction. Submarginal spines along the ventral margins of the epimera, present in a modest number in most niphargids, may completely disappear.

Telson: The telson is always longer than wide, with a deep incision and narrow lobes, usually provided with distal spines and dorsal pairs of pennate setae. In some species, the telson is extremely elongate, with very short spines (e.g., N. transitivus); dorsal setae are sometimes moved to a nearly distal position. $N$. longidactylus, an exception in this group, has comparatively long dorsal spines; we suggest this is of secondary appearance, and therefore an autapomorphy.

Antenna I: The basal article of antenna I tends to extend dorsodistally forming a "visor". Such a visor seems to be lacking in some taxa (e.g. N. pectinicauda, N. asper), while only slightly marked in others (e.g., $N$. alutensis, $N$. rostratus), and extremely developed in $N$. pupetta and $C$. paradoxa. In certain populations of $N$. transitivus (from the Piave River; cf. Sket, 1971; Karaman, 1985), the antenna $I$ is highly variable. The antenna $I$ also tends to shorten its flagellum, resulting in a reduced number of articles:

All niphargid amphipods exhibit a reduced accessory flagellum, generally with two articles. The distal article may be very short in several species, such as in $N$. carcerarius and particularly in $N$. pectinicauda, N. longidactylus, and in N. asper. In N. brevirostris, it is shorter than the diameter of the proximal article. In $N$. factor, it is present or missing. In $N$. rostratus, $N$. transitivus, and N. pupetta, the accessory flagellum seems to be always uniarticulate and sometimes very short.

Antenna II: $N$. rostratus and $N$. brevirostris seem to be an exception among niphargids, having aesthetascs on both antennae I and II.

Mandibular palp: Article 3 is longer than article 2 in most niphargids. In this group, it tends to become shorter with reduced setation. This is not found in $N$. rostratus, $N$. pectinicauda, and $N$. carcerarius.

Maxilla I: The number of setae on the inner lobe of maxilla $I$ is variable in niphargids. Most members of the group studied exhibit a low number of setae, with exception of $N$. carcerarius which has more than five setae.

The denticulation of spines on the outer lobe of maxilla I seems to be a quite variable character, perhaps enabling even populations (subspecies) of some species to adapt themselves to particular feeding conditions. In the analyzed group usually none or only the innermost spine is comb-like, but in some taxa ( $N$. longidactylus, C. paradoxa) there may be three or more such spines.

Pereiopods I-IV: Coxae of anterior pereiopods (particularly II-III) are in most niphargids only up to 50 percent as long as wide. In all species of the $N$. transitivus group, they are at least twice as long as wide. The probably primarily widened distal part of coxa IV (in $N$. alutensis, $N$. rostratus, and $N$. carcerarius) is in this group mostly only slightly widened (in $N$. asper and $N$. longidactylus) or bowshaped and parallel-sided (in remaining species).

Gnathopods: Article 6 is originally elongated and subrectangular, with subparallel anterior and posterior margins. In some taxa of the $N$. transitivus group, the margins converge in proximal direction, giving the article a triangular shape. The number of transverse posterior rows of setae is reduced in such cases, mostly to only two. The palmar margin of gnathopod II makes with the anterior margin of the article in most niphargids an acute or right angle, which angle may become obtuse by bulging of the central and/or posterior (= angular) part of the palma in distal direction.

In some species, the length of article 5 increased in relation to article 6 and may become even remarkably longer than article 6 . The originally higher number of setae on the dactyli (= article 5) is in this group (and in many other small species) usually reduced to $1-3$.

Pereiopods V-VI, coxae: The coxae of the posterior pereiopods are in nearly all other niphargids anterolobate. In the taxa included here, coxa $\mathrm{V}$ is equilobate or posterolobate, while coxa VI is always posterolobate. The anterior lobe in coxa VI is usually lacking.

Pereiopods V-VII, bases: These articles have a rounded distoposterior lobe in many niphargids. 
Some members of this group, however, have at least pereiopod $\mathrm{V}$ developed with an additional anterodistal lobe, resulting in an almost rectangular basis. While the posterior margins of bases VI-VII are sometimes broadly rounded as well, in $N$. longidactylus the bases V-VII are almost rectangular.

Pereiopods V-VII, distal articles: Article 4, originally narrow and rod-shaped or with a moderate posterior bulge, may develop a large posterior lobe, making the article very broad. In some species, the posterior pereiopods tend to shorten their distal parts (we expressed these states in the relation between lengths of articles 2 and $4+5+6$ in pereiopod VII). However, most taxa of this group have particularly thin dactyli, mostly due to elongation of nails in relation to socles. The elongation of dactyli in relation to article 6 is probably only a result of the nail elongation. Dactyli have only in $N$. pectinicauda and $N$. brevirostris a strong inner spine or spine-like seta; in most species it is reduced to a fragile seta.

Uropods I-II: Only in N. pectinicauda the originally moderate number of spines along each ramus has increased.

Uropods III: Originally they are moderately long, but they tend to become particularly short, resulting also in a reduced number of lateral spine groups. Seemingly, the exopodite developed its shape by progressing from flattened through rodshaped to subconical; unfortunately, the degree of flatness is sometimes difficult to assess. This limb underwent an extreme shortening, connected by further reduction of the terminal article, in Carinurella paradoxa.

2.2.2. Functional relation of characters. - Some characters, like pectinate spines on maxilla I and aesthetascs on antenna II, are probably the result of special adaptations. Others, like the reduction of accessory flagella on antenna I and reduction of inner spines on dactyli, could be the result of neutral mutations. Some particularities in the shape of the gnathopods as well as reductive processes in the mandibular palp's terminal article might be explained by paedomorphosis, and this is supported by the morphology of juvenile niphargids. The most extraordinary characters, designating the evo- lutionary "trend" of this group of species, are related to the upright poise and the following ability to enrol more or less into an irregular ball (volvation). This upright position seems to be a general trait of this group of species.

In niphargids, the transition from the usual locomotion on the flank to the upright poise is connected by widening of the previously laterally flattened body. In the $N$. transitivus group, the upright poise is facilitated also by a shortening of the entire body. Shortening of the distal parts of some appendages, like antennae and posterior pereiopods, seems to be the next step in this direction, achieved only by some members of the group. Probably, the deep anterior coxae and the particularly slender dactyli of the posterior pereiopods are a part of this tendency as well.

Posterolobate posterior coxae are extremely rare characters in niphargids. Supposedly they allow another direction of the pereiopod movement than is possible in the anterolobate ones. However, this supposition must be experimentally confirmed. Bousfield (1983) considers posterolobate coxae plesiomorphous, a supposition which may be correct for Amphipoda in general, but within the genus Niphargus it is correlated with so many other peculiarities (see below), that it evidently has been achieved secondarily. The next step in the same direction has obviously been an "inversion" of the pereiopod V, or/and VI, carried out by the development of a distal lobe on the anterior side of their bases. In this context, we may also explain the convexity of the anterior margin and straightening of the posterior one.

The above-mentioned morphological modifications enable some taxa to roll into a more or less irregular ball. This volvation is in fact occasionally recorded in N. alutensis (cf. Dancău, 1972). Volvation has been developed further in $N$. pupetta by the characteristic transformation of the proximal article in antenna $\mathrm{I}$, as well as by widening of proximal articles and shortening of distal ones (except for dactyli) in hind pereiopods. The niphargids' last achievement in this direction is $C$. paradoxa with its completely modified posterior part of the body and the stronger incrustation of the integument. Unfortunately, the ethology of other species is virtually 
Table I. Characters used for phylogenetic analysis of the Niphargus transitivus group and their plesiomorphous and apomorphous states (for further explanation, see text): 0 = plesiomorphous state, 1 = apomorphous state.

1. Body length:

a. (0): > $10 \mathrm{~mm}$; (1): $<8 \mathrm{~mm}$.

b. (0): $\geq 3 \mathrm{~mm}$; (1): $<3 \mathrm{~mm}$.

2. Rostrum:

(0): indistinct or very small; (1) longer than $50 \%$ of lateral head lobe.

3. Epimeron III, angle:

(0) right; (1) acute.

In the construction of the cladogram it has been supposed that the seemingly plesiomorphous state in Carinurella has been achieved secondarily; this supposition is supported by an extensive remodeling of the entire abdominal part in this species.

4. Epimera:

(0) normal; (1) extended in ventrocaudal direction. For Carinurella as in " 3 ".

5. Spines of ventral margins of epimeron III:

(0) 2-3 spines; (1) 0-1 spine.

6. Urosome:

(0) normal; (1) greatly modified.

7. Spinulation of telson:

(0) dorsal spines lacking; (1) dorsal spines present.

8. Pennate setae on telson:

(0) in or near the middle of the telson length; (1) apically or subapically.

9. Antenna I, basal article:

(0) without or with small "visor"; (1) visor longer than diameter of article, or variable.

10. Antenna I, number of flagellar articles:

(0) 9 or more; (1) 8 or less.

11. Antenna I, accessory flagellum:

(0) regularly with 2 articles; (1) 1 article or variable.

12. Antenna II, aesthetascs:

(0) absent; (1) present.

13. Mandibular palp article 3:

(0) length $\geq$ article 2; (1) length $<$ article 2.

14. Maxilla I, inner lobe:

(0) 1-3 apical setae; (1) 5 or more apical setae.

15. Maxilla I, outer lobe:

(0) none or only innermost spine comblike; (1) 3 or more comblike spines.

16. Coxae II-III:

(0) twice as long as wide; (1) more than twice as long as wide.

17. Coxa IV:

(0) distoposterior lobe large; (1) coxa only slightly wider in its distal part or parallel-sided.

18. Gnathopods, article 6:

(0) subrectangular, with subparallel anterior and posterior margins; (1) margins converge proximally, giving the article a triangular shape.

19. Gnathopod II, article 5:

(0) up to $110 \%$ of length of article 6; (1) longer.

20. Gnathopods, dactyli:

(0) more than 5 outer setae; (1) 1-3 outer setae.

21. Gnathopod II, palmar margin:

(0) makes with anterior margin of article an acute or right angle; (1) mentioned angle obtuse by bulging of the central or posterior

(= angular) part of palma in distal direction.

22. Coxa V:

(0) equilobate; (1) posterolobate.

23. Pereiopod V, article 2:

(0) without an anterodistal lobe; (1) with anterodistal lobe.

24. Pereiopod V, article 2:

(0) posterior margin convex; (1) posterior margin straight. 
Table I. Continued.

25. Pereiopod VII, article 2:

(0) posterior margin convex; (1) posterior margin straight.

26. Pereiopod V-VII, article 4:

(0) narrow; (1) with a posterior lobe, making its width equal to or larger than $2 / 3$ of the length.

27. Pereiopods VII, relation between lengths of articles 2 and $4+5+6$ :

(0) art. $2 \leq$ (art. $4+5+6$ ); (1) art. $2>$ (art. $4+5+6$ ).

28. Pereiopods V-VII, dactyli:

(0) nail shorter than socle; (1) nail equal to or longer than socle.

29. Pereiopods V-VII, dactyli:

(0) with inner spine or spine-like seta; (1) with tender seta.

30. Pereiopod VII, dactylus:

(0) article 7 shorter than $1 / 2$ of article 6; (1) it is longer.

31. Uropod I, endopodite:

(0) with 5 or less spines along its upper side; (1) with 6 or more of such spines.

32. Uropod III, proximal article of exopodite:

(0) number of lateral spine groups on one side more than 3; (1) number of such groups is 3 or less.

unknown, except for $N$. longidactylus, which is not able to volvate.

It seems plausible that Carinurella developed from a $N$. pupetta-like ancestor by some new autapomorphies and character reversals (characters 3 and 4, see Table I), which in the modified body apparently received another function.

2.2.3. Some analogies. - There are a number of amphipod taxa that have converged on the $N$. transitivus group either by retaining or regaining some characters in connection with similar movement techniques. A good representative of them is the Synurella ambulans (F. Müller, 1846) "Rassenkreis" with a similar body shape, long anterior and posterolobate posterior coxae, shortened uropods III, and in some populations also shortened articles 4-6 and long dactyli of posterior pereiopods. An interesting convergence with the $N$. transitivus group is also shown by Parapseudoniphargus baetis Notenboom, 1988 in the PseudoniphargusParapseudoniphargus complex and particularly by Parasalentinella rouchi Bou, 1971 (Bou, 1971; Notenboom, 1988a). The latter has obviously descended from a Salentinella-like ancestor, which resembled some taxa of the group analyzed here in a number of characters. In $P$. rouchi, in connection with volvation, there are also "visors" on the proximal articles of antenna I, and extremely shortened caudal appendages, making it similar to $N$. pupetta or even to C. paradoxa.

The only partial parallel within the genus Niphargus has been observed in the $N$. steueri Schellenberg, 1935 "Rassenkreis". N. steueri probably belongs to the wider $N$. orcinus Joseph, 1869 aggregate. All its races are characterized by comparatively short antennae and pereiopods, deep anterior coxae, wide bases of posterior pereiopods, and rather narrow gnathopod article 6; making this comparatively large species resemble plesiomorphic species of the $N$. transitivus group. In some races of $N$. steueri, however, the coxae V-VI are equilobate or posterolobate and the basis of pereiopod VI possesses a small anterodistal lobe (cf. Karaman, 1984b). In N. steueri liburnicus G. Karaman \& Sket, 1989, the anterodistal lobe is developed on all posterior pereiopods (V-VII) and uropod III is shorter than in any other known population of the species (Karaman \& Sket, 1989). This variable species of the centimetre category will be the most suitable subject for experimentation, which could show us the functional nature of the transformations in posterior pereiopods.

\subsection{Cladistic analysis}

2.3.1. Selection of character states. - An attempt was made to establish phylogenetic relationships within the group by cladistic analysis. According to 
Table II. Distribution of character states in the Niphargus transitivus group (for description and definition of characters and their states, see Table I and text): 0 = plesiomorphous state, 1 = apomorphous state, ? = character state unknown.

\begin{tabular}{|c|c|c|c|c|c|c|c|c|c|c|c|c|c|c|c|c|c|c|}
\hline & & $1 a$ & $1 b$ & 2 & 3 & 4 & 5 & 6 & 7 & 8 & 9 & 10 & 11 & 12 & 13 & 14 & 15 & 16 \\
\hline CA & N. carcerarius & $\mathbf{0}$ & 0 & $\mathbf{0}$ & $\mathbf{0}$ & 0 & $\mathbf{0}$ & $\mathbf{0}$ & 0 & 0 & $\mathbf{0}$ & $\mathbf{0}$ & $\mathbf{0}$ & $\mathbf{0}$ & $\mathbf{0}$ & 1 & 0 & $\mathbf{0}$ \\
\hline AS & N. asper & 1 & $\mathbf{0}$ & $\mathbf{0}$ & 1 & 1 & 0 & 0 & 0 & 0 & 0 & $\mathbf{0}$ & 0 & $\mathbf{0}$ & $\mathbf{0}$ & $\mathbf{0}$ & 0 & 1 \\
\hline FA & N. factor & 1 & 0 & 1 & 1 & 1 & 0 & $\mathbf{0}$ & 0 & 0 & $\mathbf{0}$ & 0 & 1 & $\mathbf{0}$ & 1 & $\mathbf{0}$ & $\mathbf{0}$ & 1 \\
\hline RO & $N$. rostratus & 1 & 1 & 1 & 1 & 1 & 1 & $\mathbf{0}$ & 0 & 1 & $\mathbf{0}$ & $\mathbf{0}$ & 1 & 1 & $\mathbf{0}$ & 0 & 0 & 1 \\
\hline PE & N. pectinicauda & 1 & 0 & $\mathbf{0}$ & 1 & 1 & 1 & $\mathbf{0}$ & 0 & 0 & $\mathbf{0}$ & $\mathbf{0}$ & $\mathbf{0}$ & $\mathbf{0}$ & 0 & 0 & 0 & 1 \\
\hline LO & N. longidactylus & 1 & 0 & $\mathbf{0}$ & 1 & 1 & 1 & 0 & 1 & 0 & $\mathbf{0}$ & 0 & 0 & $\mathbf{0}$ & 1 & 0 & 1 & 0 \\
\hline $\mathbf{A L}$ & $N$. alutensis & 1 & 1 & $\mathbf{0}$ & 1 & 1 & 1 & 0 & 0 & 1 & 0 & 1 & 0 & 0 & 0 & 0 & 0 & 0 \\
\hline NU & N. numerus & 1 & 0 & $\mathbf{0}$ & 1 & 1 & 1 & 0 & 0 & 0 & 0 & 1 & 1 & 0 & 0 & 0 & 0 & 1 \\
\hline BR & N. brevirostris & 1 & 0 & 1 & 1 & 1 & 1 & 0 & 0 & 0 & 0 & 1 & 0 & 1 & 0 & 0 & 0 & 1 \\
\hline TR & N. transitivus & 1 & $?$ & $\mathbf{0}$ & 1 & 1 & 1 & 0 & 0 & 0 & 1 & $\mathbf{0}$ & 1 & 0 & 1 & 0 & $\mathbf{0}$ & 1 \\
\hline PU & $N$. pupetta & 1 & 1 & $\mathbf{0}$ & 1 & 1 & 1 & $\mathbf{0}$ & 0 & 0 & 1 & 1 & 1 & 0 & 1 & 0 & 0 & 1 \\
\hline \multirow[t]{2}{*}{$\mathbf{C P}$} & C. paradoxa & 1 & 0 & 0 & 1 & 1 & 1 & 1 & 0 & 0 & 1 & 1 & 1 & 0 & 1 & 0 & 1 & 1 \\
\hline & & & 17 & 18 & 19 & 20 & 21 & 22 & 23 & 24 & 25 & 26 & 27 & 28 & 29 & 30 & 31 & 32 \\
\hline CA & N. carcerarius & & $\mathbf{0}$ & $\mathbf{0}$ & 0 & 0 & $\mathbf{0}$ & $\mathbf{0}$ & 0 & 0 & 0 & $\mathbf{0}$ & $\mathbf{0}$ & $\mathbf{0}$ & 1 & $\mathbf{0}$ & $\mathbf{0}$ & $\mathbf{0}$ \\
\hline AS & $N$. asper & & $\mathbf{0}$ & 0 & 0 & 1 & 0 & $\mathbf{0}$ & 1 & 1 & 0 & $\mathbf{0}$ & 0 & 0 & 1 & 0 & $\mathbf{0}$ & 1 \\
\hline FA & N. factor & & 1 & 0 & 0 & 1 & 0 & $\mathbf{0}$ & 1 & 0 & 0 & $\mathbf{0}$ & $\mathbf{0}$ & 0 & 1 & 1 & 0 & 1 \\
\hline RO & $N$. rostratus & & 0 & 0 & $\mathbf{0}$ & 1 & 1 & $\mathbf{0}$ & 0 & 0 & 0 & 0 & $\mathbf{0}$ & 1 & 1 & 1 & 0 & $\mathbf{0}$ \\
\hline PE & N. pectinicauda & & 1 & 0 & 0 & 1 & 0 & $\mathbf{0}$ & 1 & 1 & $\mathbf{0}$ & $\mathbf{0}$ & $\mathbf{0}$ & 0 & 0 & 0 & 1 & 0 \\
\hline LO & N. longidactylus & & 0 & 0 & 1 & 1 & 1 & 1 & $?$ & 1 & 1 & $\mathbf{0}$ & $\mathbf{0}$ & 1 & 1 & 1 & 0 & 0 \\
\hline $\mathbf{A L}$ & N. alutensis & & 0 & 1 & 1 & 1 & 0 & 0 & 1 & 1 & 0 & 0 & 0 & 1 & 1 & $?$ & 0 & 1 \\
\hline NU & N. numerus & & 1 & 0 & 0 & 1 & 0 & 0 & 1 & 1 & 0 & 1 & 1 & 1 & 1 & 1 & 0 & 1 \\
\hline BR & N. brevirostris & & 1 & 0 & 0 & 1 & 1 & 0 & 1 & 1 & 0 & $\mathbf{0}$ & 1 & 1 & 0 & 1 & 0 & 1 \\
\hline TR & N. transitivus & & 1 & 1 & 1 & 1 & 0 & 1 & 0 & 1 & $\mathbf{0}$ & $\mathbf{0}$ & 1 & 1 & 1 & 1 & 0 & 1 \\
\hline PU & N. pupetta & & 1 & 1 & 1 & 1 & 1 & 1 & 1 & 1 & $\mathbf{0}$ & 1 & 1 & 1 & 1 & 1 & 0 & 1 \\
\hline $\mathrm{CP}$ & C. paradoxa & & 1 & 1 & 1 & 1 & 1 & 1 & 0 & 1 & 1 & 1 & 1 & 1 & 1 & 1 & $\mathbf{0}$ & 1 \\
\hline
\end{tabular}

the discussion in the above sections, a set of characters was chosen and we tried to define their most representative and exactly measurable states. The selected characters are given in Table I and their distribution over the species in Table II.

2.3.2. Numerical cladistic analysis. - The data matrix of the $N$. transitivus group (Table II) with the exclusion of autapomorphous $(6,7,14,31)$ and doubtful $(1 \mathrm{a}, 15,20,29)$ characters has been analyzed with the MIX, PENNY, and CLIQUE programs of the PHYLIP phylogeny inference package (Felsenstein, 1987) version 3.01. Cladograms were constructed under Wagner (Eck \& Dayhoff, 1966; Kluge \& Farris, 1969) and Camin-Sokal (Camin \& Sokal, 1965) parsimony options. Under the CaminSokal criterion, character reversals are not permitted. The parsimony orientated programs (MIX and PENNY) attempt to minimize the number of character state changes in order to explain the pattern of character state distribution among the taxa. The most parsimonious cladograms found under similar premises were evaluated by comparing their topologies and the distribution of synapomorphies. The consistency index is used as a tool for cladogram comparison; it is defined by the theoretical minimum number of character state changes divided by the actual number of changes. The consistency index is 1 in case cladograms contain no homoplasies. Rooting of cladograms is done by specifying the ancestral states for each character. Strict consensus cladograms are constructed on the basis of PHYLIP CONSENSE. Compatibility analysis (Le Quesne, 1969) is performed by PHYLIP CLIQUE. This method searches for the largest collection(s) of mutually compatible characters (clique(s)).

Compatibility analysis of the data shows a high 


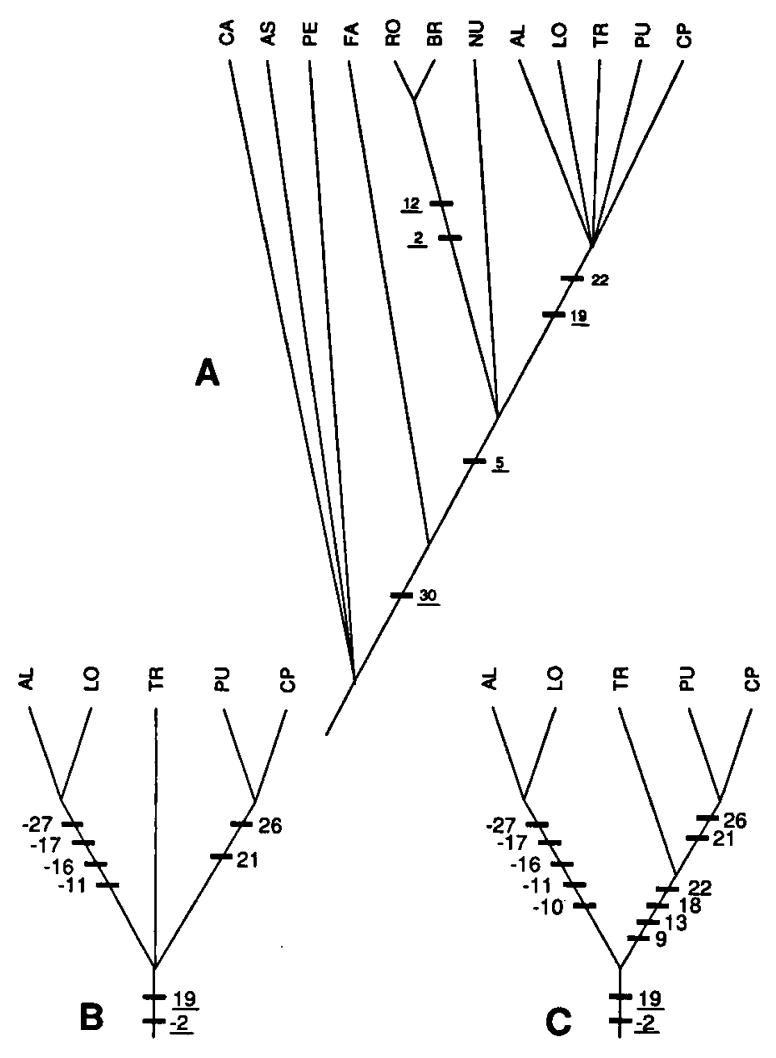

Fig. 1. Strict consensus cladograms of the $N$. transitivus group constructed by numerical cladistic analysis (see text for explanation). Species name abbreviations are explained in Table II. Matching synapomorphies indicated only, uniquely derived characters underlined, character state reversals indicated by minus-sign. A, cladogram identical for both Wagner and Camin-Sokal parsimony analysis; B, cladogram inferred by Wagner parsimony method after secondary analysis of the $N$. transitivus group s. str.; C, same as B, but inferred using the Camin-Sokal parsimony method.

level of inconsistency. Ten largest cliques of 8 characters each are found. Five characters $(3,4,12$, $19,30)$ are in the intersection of all these cliques and 12 characters $(1 b, 2,3,4,5,9,12,18,19,22,25$, 30 ) in the joining of them. The characters in intersection of the cliques convincingly indicate the monophyly of the following subsets of species: (1) all species with exception of $N$. carcerarius, $N$. pectinicauda, and $N$. asper; (2) N. brevirostris and $N$. rostratus; and (3) $N$. longidactylus, $N$. alutensis, $N$. transitivus, N. pupetta, and Carinurella para- doxa. To facilitate discussion, the third subset is considered the $N$. transitivus group s. str.

Parsimony analysis of all data leads to a large number $(+100)$ of equally parsimonious cladistic solutions. The consistency indices of the cladograms constructed with the Wagner method is 0.45 , and 0.40 when the Camin-Sokal method is chosen. The different solutions show little agreement in the monophyletic groups they support.

To arrive at a more consistent picture, the characters not present in any of the ten largest cliques, thus those with a high probability of not being homologous, are excluded from analysis. The cladograms constructed with this reduced data set are all similar in topology and in the monophyletic groups they support, whether obtained under Wagner or Camin-Sokal options. They always have a consistency index of 0.75 . However, there is no unique dichotomous solution indicating that polychotomous branching patterns exist that could not be resolved. The consensus of the cladograms generated under both parsimony options is given in Fig. 1A.

There are some arguments in favour of giving the characters $4,5,10,24,27$, and 28 , a greater importance in the phylogeny reconstruction. Therefore all numerical analyses performed have been executed with both weighed and unweighed characters. However, a weighing procedure has not resulted in a different class of cladistic solutions. The whole argument in favour of a greater weight for certain characters has therefore not been treated in more detail.

A secondary analysis of the $N$. transitivus group s. str. has been executed with parsimony methods. The ancestral character states of this group have been estimated using outgroups (other species of the $N$. transitivus group s.1.) and parsimony, applying rules given by Maddison et al. (1984). The Wagner analysis reveals two cladograms (consensus tree in Fig. 1B) and the Camin-Sokal analysis a single one (Fig. 1C); the consistency index of all three cladograms is 0.89 . Noteworthy are reversals in characters $11,16,17$, and 27 constituting synapomorphies for the sister species $N$. longidactylus and $N$. alutensis. 


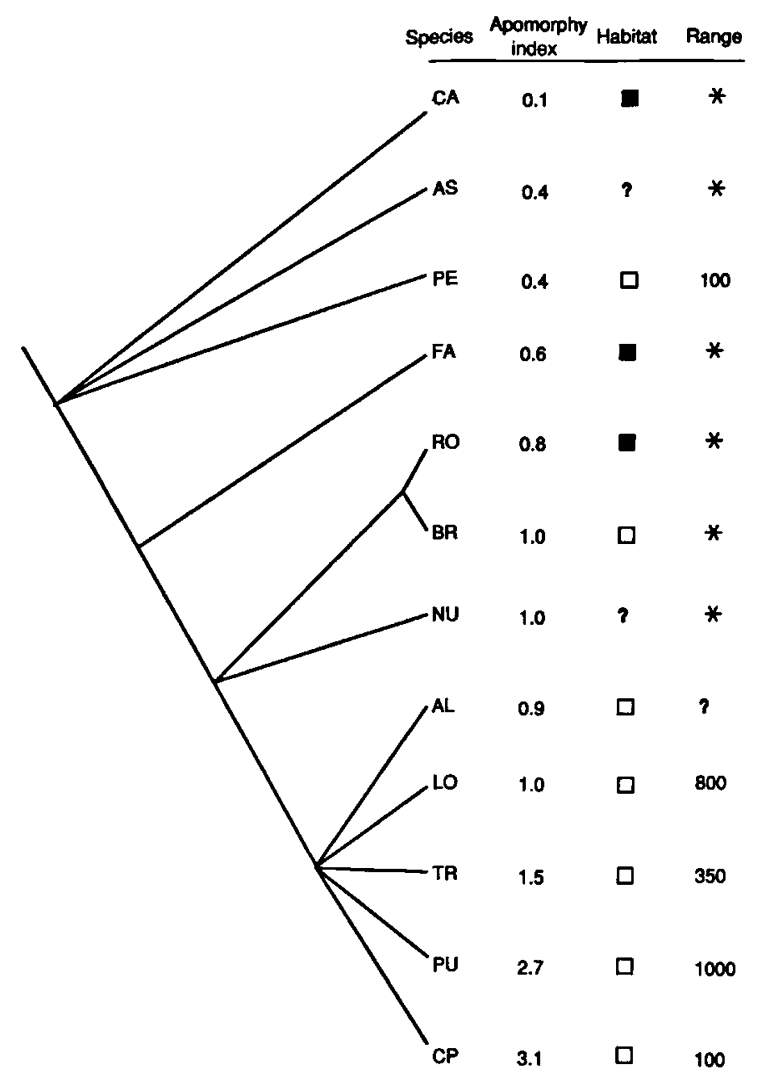

Fig. 2. Apomorphy indices of the species of the $N$. transitivus group, compared with their positions in the cladogram and their ecological and geographical ranges. Species indications as in Table II; for explanation of the use of "apomorphy indices", see text. Habitat: $\square$ = caves; $\square=$ interstitial; ? = proper habitat uncertain. Range: whole numbers denote length of ranges in $\mathrm{km} ;{ }^{*}$ = species known from one single locality only in the heart of the Dinaric karst.

\section{Some biogeographic reflections}

Prior to a biogeographic analysis we decided to establish the relative position of individual taxa along the main evolutionary path of the group. This is done by counting "apomorphy indices" by dividing numbers of apomorphies by numbers of plesiomorphies. One has to emphasize that those indices have only a relative significance, only for the chosen set of characters and species, characterizing mostly the developmental "direction" of the group. The indices have not a single meaning for the phylogenetic relationships among taxa.
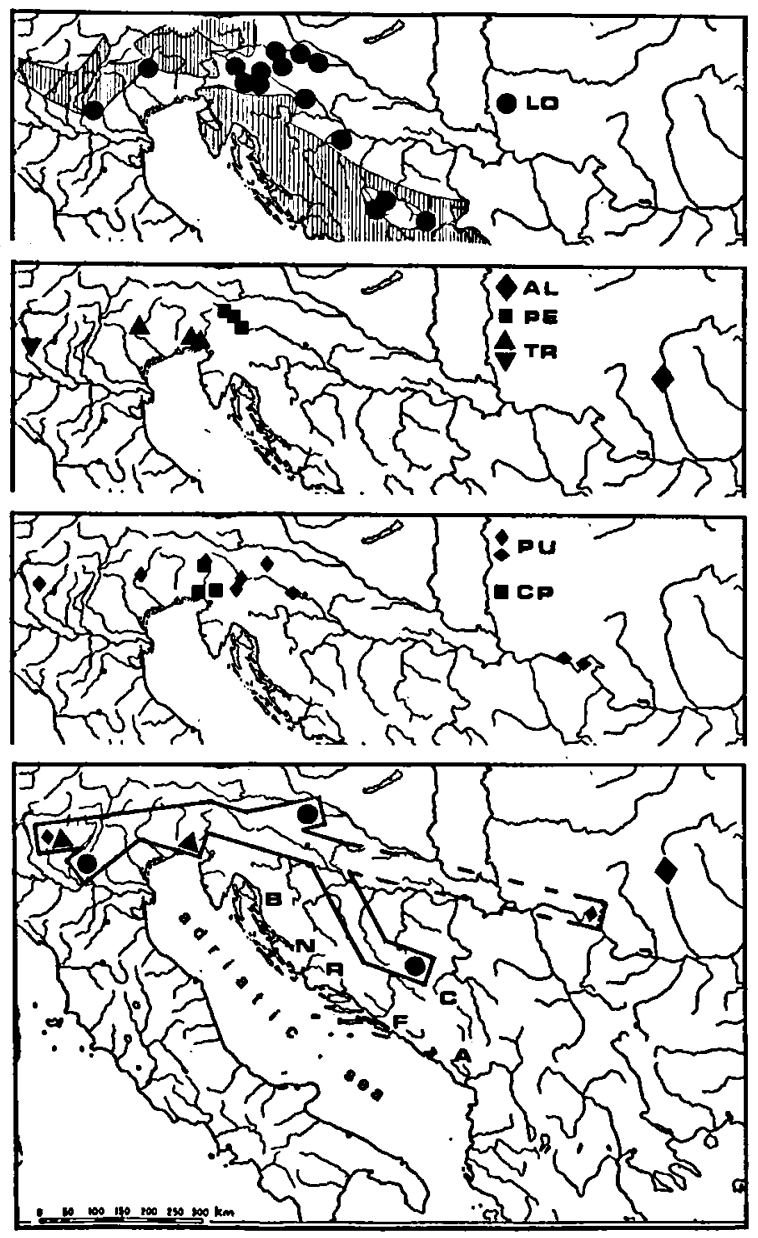

Fig. 3. Distribution area of the $N$. transitivus group (for $N$. alutensis only an approximate position could be given). The lowest map shows localities of the Dinaric species and the composed track of the interstitial species. The important karst areas are indicated only on the topmost map. Species indications as in Table II; double symbols for TR and PU for different subspecies (see text); in the lowest map the letters indicate species known from one single locality in the heart of the Dinaric karst: B $=N$. brevirostris, $\mathbf{N}=N$. numerus, $\mathrm{R}=N$. rostratus, $\mathrm{F}=N$. factor, $\mathrm{C}=N$. carcerarius, $\mathrm{A}=N$. asper.

It is evident (Fig. 2) that taxa with higher apomorphy indices are mostly inhabitants of interstitial waters outside the karst regions. As much as they approach karst regions, they always inhabit nonkarstic habitats at their borders (in the fluviokarst). Cave inhabitants in the Dinaric heartland exhibit mostly relatively low apomorphy. Inside the Dinaric karst, the apomorphy indices are increasing in direction from southeast towards northwest. 
Taxa with high apomorphy indices generally exhibit larger distribution ranges, but this may be due to their interstitial habitat. Although $N$. alutensis has been mentioned from only one locality, it is very probable that its range is much larger. It may extend either along the Olt River or parallel the Danube, across its Transilvanian tributaries, similar to the situation in Italy and Slovenia.

According to the distribution of the group (Fig. 3 ) in the territory between the ancient Tethys and Paratethys, it is most probable that it originated before the karst development during the Pliocene. It is, however, possible that either (1) the epigean ancestor dispersed through freshwater connections of the northern Aegeis, or (2) it invaded the territory polytopically, by isolated confluents of the Paratethys, also where speciation started, or (3) the group was formed by step by step penetration and speciation from a "centre of origin" in the southeast towards the northwest (in the sense of the "progression rule"). Increasing apomorphy indices in northwestern direction seems at first glance to be an argument in favour of the third option.

The most plesiomorphic species inhabit karstic cave waters in the southeastern Dinaric Alps (the somehow less plesiomorphic $N$. brevirostris was found in interstitial waters of a karst polje and the related $N$. numerus might belong to the same habitat - see above). Nevertheless, we hesitate to assume that the group originated in caves. Since most species are extremely small, and since interstitial waters existed before the karstic habitats, it is more probable that the cave species of today have found within caves a refugium from competition of the more highly evolved interstitial relatives. Cave species are apparently adapted to particular niches in comparison with other karstic Niphargus spp. Their method of locomotion probably must be understood in this context.

Species of the $N$. transitivus group that inhabit karst exhibit very small distribution ranges, which may be due to the large degree of isolation in small subunits of the hydrographic system of the Dinaric Alps. By contrast, non-karstic species have large (i.e. long) ranges. After an initial allopatric speciation in confluents of the Paratethys, they may have had much greater possibilities to disperse by inter- stitial waters, particularly during the AlpinoDinaric orogenesis, when most rivers had to change their directions at least temporarily along the thrusting fault zones; this is also the main axis of the ranges of non-karstic species. So the species that were previously isolated became in part sympatric.

The composed track (see lowest map in Fig. 3), circumscribing ranges of the monophyletic nonkarstic part of this group, seems to be congruent with distribution ranges of some other aggregates within the genus Niphargus as well as with other interstitial Crustacea (e.g. a part of the $N$. jovanovici aggregate, cf. Sket, 1972; see Sket, in prep., for discussion).

\section{Summary and conclusions}

In the area between northeastern Italy, through the Dinaric Alps to southern Rumania, 12 nominal species of the $N$. transitivus group are known. The species are morphologically distinct, forming an aberrant cluster within the genus. However, as descriptions of several species of the cluster are based on very poor material, and variation within or between adjacent populations is lacking, it cannot be excluded that some nominal species are intraspecific unities.

Within Niphargus, the $N$. transitivus group probably is most closely related to the $N$. kochianus complex which includes some species with single $N$. transitivus group characters. The distinctively mosaic type evolution within the whole genus makes exact delimitation of any group extremely difficult. The $N$. transitivus group is characterized by upright posture, and a step by step adaptation to volvation. The accumulated result of this phyletic lineage is Carinurella paradoxa. However, by exclusion of Carinurella (along with some other established genera) from Niphargus the latter is made a paraphyletic entity.

The species of the $N$. transitivus group inhabit interstitial waters or caves in small areas of the Dinaric karst and extensive areas to the north. We propose that the initial speciation of an ancestor, arriving from the Paratethys, occurred in its southern confluents. During the Alpino-Dinaric orogenesis 
(and subsequent karstification) some conservative taxa could have escaped into isolated karstic areas while others overlapped the areas owing to changed drainage directions.

The phylogenetic analysis suffers from a large inconsistency in the data and the results are not sufficiently robust to be convincing. Possible explanations for inconsistencies are discussed by Notenboom (1988b: 188-192): (1) There are general problems when cladistic analysis is applied at low taxonomic levels (Arnold, 1981). This may be a reflection of a very similar gene pool shared by the species, so that true parallelisms are likely to occur; the simplicity of the available characters, which renders homoplasies difficult to detect and character polarity less easily to ascertain; the shortage of available characters, with the consequence that errors made in the recognition of synapomorphies have a proportionally large influence on the final result; and the fact that polymorphism frequently increases errors made in selection of appropriate characters. (2) Development of cave-dependent structural reductions and troglomorphisms may easily evolve independently, and this phenomenon can in turn result in character incompatibility. (3) Underlying peripatric mechanisms of speciation can result in polychotomous patterns of descent as evidenced by synapomorphies (Notenboom, 1991). (4) There are no reasons to assume that the most parsimonious cladogram or the largest clique represent the best estimate of phylogenetic relationships. Thus, the inference of phylogenetic and biogeographic patterns with the aim to elucidate the evolutionary history of the $N$. transitivus group is strongly handicapped by this large inconsistency in the data.

\section{References}

Ancona, U. d', 1942a. Variabilità, differenziamento di razze locali e di spezie nel genere Niphargus. Memorie Ist. ital. Idrobiol. Dr. Marco Marchi, 1: 145-167.

Ancona, U. d', 1942b. I Niphargus italiani. Tentativo di valutazione critica delle minori unità sistematiche. Memorie R. Ist. Speleol. ital., (Biol.) 4: 1-225.

Arnold, E.N., 1981. Estimating phylogenies at low taxonomic levels. Z. zool. Syst. Evolut.-forsch., 19: 1-35.
Benedetti, G., 1942. Prime osservazioni sopra i Niphargus della Venezia Euganea. Memorie R. Accad. Sci. Lett. Arti Padova, 58: $1-15$.

Bou, C., 1971. Recherches sur les eaux souterraines, 16. Parasalentinella rouchi n. g., n. sp., des eaux souterraines des Pyrénées françaises (Amphipoda, Gammaridae). Annls. Spéléol., 26: 481-494.

Bousfield, E., 1983. An updated phyletic classification and paleohistory of the Amphipoda. In: F.R. Schram (ed.), Crustacean phylogeny: 257-277 (A.A. Balkema, Rotterdam \& Boston).

Camin, J.H. \& R.R. Sokal, 1965. A method for deducing branching sequences in phylogeny. Evolution, 19: 311-326.

Dancău, E., 1971. Sur un nouvel Amphipode souterrain de Roumanie, Niphargus alutensis n. sp. Trav. Inst. Spéol. Emile Racovitza, 10: 209-215.

Dancău, D., 1972. Sur la présence en Roumanie du genre Karamaniella (Amphipoda). Trav. Inst. Spéol. Emile Racovitza, 11: 225-231.

Eck, R.V.\& M.O. Dayhoff, 1966. Atlas of protein sequence and structure (National Biomedical Research Foundation, Silver Springs, Maryland).

Felsenstein, J., 1987. PHYLIP (Phylogeny Inference Package) version 3.0 manual. Available from the author, c/o University of Washington, Department of Genetics SK-50, Seattle, Washington 98195, USA.

Karaman, G.S., 1972. XXXVII contribution to the knowledge of the Amphipoda. Niphargus asper, n. sp., Echinogammarus foxi (Schell.) and E. stocki G. Kar. (fam. Gammaridae) from Yugoslavia. Acta Mus. maced. Sci. nat., 13: 1-18.

Karaman, G.S., 1975. 73. Contribution to the knowledge of Amphipoda. Three Niphargus species from Yugoslavia and Italy, N. ambulator n. sp., N. pupetta (Sket) and N. transitivus Sket (fam. Gammaridae). Poljoprivreda i Sumarstvo, Titograd, 21(4): 13-34.

Karaman, G.S., 1981. Description and distribution of Niphargus longidactylus Ruffo in Yugoslavia and Italy (fam. Gammaridae) (Contribution to the knowledge of Amphipoda 115). Biosistematika, 7: 39-49.

Karaman, G.S., 1984a. Description of several new Niphargus species (Gammaridea, Niphargidae) from southern Europe (Contribution to the knowledge of the Amphipoda 136). Poljoprivreda i Sumarstvo, Titograd, 30(2-3): 39-64.

Karaman, G.S., 1984b. Revision of the Niphargus orcinusgroup, part I. (fam. Niphargidae) (Contribution to the knowledge of the Amphipoda 130). Crnogorska Akademija Nauka i Umjetnosti, Glasnik Odjeljenja prirodnih Nauka, 4: 7-79.

Karaman, G.S., 1985. The taxonomy of Niphargus transitivus Sket, 1971 with remarks to N. armatus G. Kar., 1985 (fam. Niphargidae) in Italy (Contribution to the knowledge of the Amphipoda 149). Poljoprivreda i Sumarstvo, Titograd, 31(2-3): 21-35.

Karaman, G.S., 1989. New species of family Niphargidae and new localities of some other subterranean gammaridean species from Yugoslavia (Contribution to the knowledge of the 
Amphipoda 166). Glasn. rep. Zav. Zašt. Prir. prir. Muz. Titograd, 19 “1986”: 15-32.

Karaman, G.S. \& B. Sket, 1989. Niphargus species (Crustacea: Amphipoda) of the Kvarner-Velebit Islands (NW Adriatic, Yugoslavia). Biol. Vèstn., 37(2): 19-36.

Karaman, G.S. \& B. Sket, 1991. Two new Niphargus species (Amphipoda) from caves in Yugoslavia. Int. J. Speleol., 19: 51-66.

Kluge, A.G. \& J.S. Farris, 1969. Quantitative phyletics and the evolution of anurans. Syst. Zool., 18: 1-32.

Maddison, W.P., M.J. Donoghue \& D.R. Maddison, 1984. Outgroup analysis and parsimony. Syst. Zool., 33(1): 83-103.

Notenboom, J., 1988a. Parapseudoniphargus baetis, new genus, new species, a stygobiont amphipod crustacean from the Guadalquivir river basin (southern Spain), with phylogenetic implications. J. crust. Biol., 8: 110-121.

Notenboom, J., 1988b. Phylogenetic relationships and biogeography of the groundwater-dwelling amphipod genus Pseudoniphargus (Crustacea), with emphasis on the Iberian species. Bijdr. Dierk., 58(2): 159-204.

Notenboom, J., 1991. Marine regressions and the evolution of groundwater dwelling amphipods (Crustacea). J. Biogeogr., 18(4): 437-454.

Quesne, W.J. le, 1969. A method of selection of characters in numerical taxonomy. Syst. Zool., 18(2): 201-205.

Ruffo, S., 1937. Studi sui Crostacei Anfipodi VI. Un nuovo Niphargus delle acque soterranee del Veneto. Boll. Ist. Ent. Univ. Bologna, 10: 24-30.
Sket, B., 1962. Karamaniella pupetta n. g., n. sp., ein neuer Amphipode aus Slovenien. Izd. Zav. Ribarst. N.R. Maked., Skopje, 3(2): 27-32.

Sket, B., 1964. Nova aberantna vrsta postranic (Crust., Amphipoda) iz Slovenije (Eine neue aberrante Art der Flohkrebse aus Slovenija). Biol. Věstn., 12: 147-152.

Sket, B., 1971. Vier neue aberrante Niphargus-Arten (Amphipoda, Gammaridae) und einige Bemerkungen zur Taxonomie der Niphargus-ähnlichen Gruppen. Razpr. slov. Akad. Znan. Umet., (Cl. IV) 14(1): 1-25.

Sket, B., 1972. Die Niphargus jovanovici-Gruppe (Amphipoda, Gammaridae) in Jugoslawien und NO-Italien, taxonomisch, zoogeographisch und phylogenetisch betrachtet. Razpr. slov. Akad. Znan. Umet., (Cl. IV) 15(1): 99-141, maps 1-2.

Sket, B., 1990. Is Niphargobates lefkodemonaki sp. n. (Crustacea: Amphipoda) from Kriti (Greece) a zoogeographical enigma? Zool. Jb., (Syst.) 117: 1-10.

Sket, B., in prep. Distribution patterns of some subterranean Crustacea in the territory of the former Yugoslavia.

Sket, B. \& F. Velkovrh, 1981. Phreatische fauna in Ljubljansko polje (Ljubljana-Ebene, Jugoslavien) - ihre ökologische Verteilung und zoogeographische Beziehungen. Int. J. Speleol., 11: $105-121$.

Received: 1 June 1992

Revised: 5 April 1993 